\title{
ARTISTIC REPORTAGES \\ BY O. KRYSHTOPA'S UKRAINE: THE SCOPE 1:1
}

\section{Lenok Maria}

Postgraduate student

ORCID ID 0000-0002-3954-0691

Zaporizhzhia National University

66, Zhukovskoho St., Zaporizhzhia, 69063, Ukraine

lenmarii@i.ua

The article is devoted to artistic reportages by O. Khrystopa a Ukrainian author of non fiction literature. The artistic reportage of the early 21 st century underwent significant changes, evolving from the literary coverage of the 1920s. Contemporary authors refine their texts with different artistic techniques, genre-style techniques, which leads to the emergence of common genres. Such texts tend to be meta-genre in documentary and artistic discourse. The artistic reportages have a dual nature because they synthesize genre features of literature and journalism. There is a tendency to saturate artistic reportage with artistic techniques, expanding the possibilities of literature today.

The aim of the article is to find out the place of artistic reportage in the contemporary Ukrainian literary discourse and to analyze some texts, in particular the book by O. Khrystopa's Ukraine: the Scope 1:1.

The author represented a map of his travels and assignments to different corners of the country, covering a number of small and large cities. It is noteworthy that he reproduced urgent topics: unemployment, employment, language, politics, ecology, coal fever, Chornobyl.

The artist skillfully uses linguistic and imaginative means that focus on poetic microimages in the texts of artistic reportages in the book Ukraine: the Scope 1:1. The sound and visual images give the texts the proof.

The artist imposes the text with the metaphorical, metonymic or amplifying character, uses simple comparisons, synecdoche, often parses a narrative that helps to focus on the background of the image; expresses the artistic background with literary allusions, preserving the tradition of considering one text within another.

The study of the genre specificity of the artistic reportage will be the subject of the further research.

Key words: meta-genre, non-fiction, fact, reportage, artistic reportage.

\section{ХУДОЖНІ РЕПОРТАЖІ \\ О. КРИШТОПИ «УКРАЇНА: МАСШТАБ 1:1»}

\author{
Ленок Марія \\ Аспірант кафедри української літератури \\ ORCID ID 0000-0002-3954-0691 \\ Запорізький національний університет, \\ вул. Жуковського, 66, м. Запоріжжя, 69063, Україна \\ lenmarii@i.ua
}

У статті розглянуто художні репортажі О. Криштопи - украӥнського автора літератури нон-фікщн. Художній репортаж початку ХХІ століття зазнав істотних змін, еволючіонуючи від літературних репортажів 1920-х років. Сучасні автори удосконалюють тексти різними мистеиькими прийомами, жанрово-

(C) Lenok M., 2020 
стильовими техніками, щуо призводить до виникнення спільних жанрів. У документально-художньому дискурсі такі тексти тяжіють до метажанрових. Художні репортажі мають двоїсту природу, тому щзо синтезують жанрові особливості літератури та журналістики. Сьогодні домінує тендениія насичувати художній репортаж мистецьькими прийомами, розширюючи можливості літератури.

Мета статті - з'ясувати місие художнього репортажу в сучасному украӥнському літературному дискурсі та проаналізувати тексти, зокрема книги О. Криштопи "Украӥна: маситаб 1:1».

Автор зобразив у книзі картографію власних мандрівок $i$ відряджень різними куточками краӥни охоплює низку малих і великих міст. Примітно, щзо він висвітлив злободенні теми: безробіття, заробітчанство, мова, політика, екологія, вугільна лихоманка, Чорнобиль.

У книзі «Україна: масштаб 1:1» митець уміло користується мовностилістичними й образними засобами, які акцентують увагу на поетичних мікрообразах у текстах художніх репортажів. Звукові й зорові образи надають текстам правдивості.

Митецьь наснажуе метафоричним, метонімічним чи ампліфікаційним характером тексти, використовує прості порівняння, синекдоху, часто париелює оповідь, яка допомагає кониентрувати увагу на фоні зображення; увиразнює художнє тло літературними алюзіями, зберігаючи традицію розгляду одного тексту в межах іншого.

Дослідження жанрової специфіки художнього репортажу може бути предметом подальших розвідок.

Ключові слова: метажанр, нон-фікшн, факт, репортаж, художній репортаж.

Problem statement. Today the literature of fact or "non-fiction literature" (M. Varykasha, O. Halych, A. Halych, N. Koloshuk, T. Cherkashyna), "non-fictional literature" (O. Rarytskyi) [2, p. 16] is perceived as a necessity. So the issue of genrespecific features of artistic reportage acquires great importance. Outlining the documentary basis and the need to record the reality artistically, we point to its syncretic nature.

The term "new journalism" is an acquisition of the American literature, and it later originated in other national literatures, in Germany in particular - "die literarische Reportage", in Poland - "the literature of fact", and in the contemporary Ukrainian literature - the artistic reportage. Today it is "a unique Ukrainian literary and reportage non-fiction hybrid" [9] (M. Tytarenko, L. Shutiak, O. Yaremchuk) because it appeared on the edge between literature and journalism. The artistic reportage reveals a genealogical resemblance with the documentary meta-genre, in which various stylistic elements are combined.

The genre system of literature is developing rapidly, because its components interact. The concrete embodiment of these processes was explored by N. Kopystianska, who emphasized that the combination of different types of art leads to the fact that "... it is possible to talk about "common" genres..." [5, p. 63]. Ts. Todorov emphasized that literature is "a system undergoing continuous transformation..." [10, p. 25]. Sharing the views of T. Bovsunivska and O. Rarytskyi, we affirm that artistic reportage belongs to the meta-genre as "extra-urban and inter-genre formation" [8, p. 47], which can “... easily accept genres of not only different kinds of literature but also genres of different kinds of art" [1, p. 11].

The literary encyclopedia presents a reportage as “... an informative operative genre of journalism..." in which the author is able to "... think of only some logical connections between the illuminated facts, resort to emotion, laconicism, and dynamism of the style...", and the text can "... sometimes grow into a literary narrative" [7, p. 315]. As for the artistic component, it is complemented by specific techniques of image creation (scene framing, sensibility, intertextuality, a wide range of stylistic means of poetic writing, humor, etc.). 
So, T. Bovsunivska's statement that "any genre can borrow specific features of other genres and significantly change its internal appearance and order" [1, p. 8] is absolutely correct. The artistic reportage combines different genre-style techniques, raises serious problems, shows the presence of the author, deeply unfolds images that are specified by artistic means.

The artistic reportage gained popularity in Ukrainian literature in 1920s. It is known that it was the time of creative search, the desire for experimentation. Ya. Tsymbal emphasized that the reportage was the acquisition of writers, and therefore we consider it a literary phenomenon: "There were several decades left before the mass television ..." [12]. B. Antonenko-Davydovych (collections "Earth Ukrainian", "The People and Coal", "Zbruch"), S. Golovanivskyi ("The Boot of Europe"), O. Dosvitnii ("Heroes of the Dawn"), M. Yohansen ("Three Travels", "Traveling of a Man under the Cap"), K. Kotko ("The Sun under Minarets"), O. Maryamov ("Paths under the Sun (10,000 kilometers)", "Airports and Ports"), S. Sklyarenko ("Three Republics"), M. Trublaini ("Letters from the Long Journey", "The Great Siberian Way", "To the Arctic through the Tropics"), etc worked in this meta-genre.

We trace the features of the artistic reportage in the diary entries published in the books by O. Zabuzhko's "Let my People Go: 15 Texts About the Ukrainian Revolution" and by M. Matios "Pages Torn from the Autobiography". The writers demonstrated the skills of writing close to the techniques of the "new journalism", which led to the revival of stylistic features of the artistic reportage as a literature-critical meta-genre in the contemporary Ukrainian literary process. The creators of the Ukrainian artistic reportage are L. Belei, N. Gumeniuk, V. Ivchenko, D. Kazanskyi, O. Kryshtopa, M. Pedorenko, M. Semenchenko, P. Stekh, O. Yaremchuk, etc.

Analysis of recent research and publications. In American literature the genre of the "new journalism" is actively developing. K. Kerren and B. Yagoda and L. Williford and M. Marton dealt with the development and functioning of the "new journalism". O. Mykhed explored the role of the "new journalism" in the process of forming an autobiographical reality novel through the lens of literary criticism. M. Tytarenko, the author of "The Lab of Reportage" at the "LitAktsent" website, was the first to articulate the "new journalism" in Ukraine and to promote it actively in the media sphere. L. Shutiak represents it in the media discourse of Ukraine. Thus, the artistic reportage is of interest for the study of its genre nature in the literary studies.

The purpose of the article is to clarify the place of the artistic reportage in the contemporary Ukrainian literary discourse and to analyze some works, in particular O. Khrystopa's book "Ukraine: 1:1 the Scale". To achieve this goal it is necessary to perform the following tasks: to determine the artistic reportage's genre-style specificity, to consider the role of the reportage in the literary discourse as a component of non-fiction, to identify the means of linguistic expression in O. Kryshtopa's artistic reportages.

In this paper the analytical-descriptive method was used, in particular the selection, the systematization, the description and the analysis of the material and also the biographical method.

The object of the research is the artistic reportages "Ukraine: the Scope 1:1" by O. Kryshtopa.

The subject of the research is the linguistic and stylistic devices expressed in different contexts in the author's book.

Statement of the main material. Facts are the translators of the objective reality, but "the writer, due to special literary devices and his/her skill, can turn them into a factor of emotional influence on the reader without crossing the boundaries of fiction" [11, p. 9]. So the picture of real events is deepened by a certain set of artistic devices.

$\mathrm{V}$. Donchyk summarizing the achievements of the documentary literature, asserted that "... the literature of fact according to some Western theorists and practitioners of literature has, until recently, offered up, as they say, the logical and the only replacement for an old novel, according to their forecasts, fiction or "collage texts" and in general, the new 
journalism is the one that most closely matches the time... " [3, p. 367]. O. Halych assures that the Ukrainian literature, as well as the European literature, will be based on the "documentary literature" $[2$, p. 10] in the future.

In Ukraine for seven years in a row, they held a Competition in Artistic Reportage "Samovydets" named after Mike Johansen. In his afterword to the collection "Three Travels" M. Johansen stated: "... I wrote this book (and thus began a new thing for the Ukrainian literature." [11, p. 8]. The artistic reportage of the early 21 st century has changed, evolving from literary reportages of 1920's. For the most part, this applies to various techniques and genres used in the texts.

It is not worth to associate the origin of the Ukrainian reportage with journalism only. O. Ilnytskyi researching Ukrainian futurist writers, argued that "... Ukrainians preferred to experiment with genres and narrative structures, "destroying" literature and at the same time creating unknown forms. The literature of fact was resorted not for its own sake, but as an opportunity to combine techniques of journalism with the artistic ones" [4, p. 376]. Today there is a tendency to saturate artistic reporting with different artistic techniques, expanding the possibilities of literature.

O. Khryshtopa is a journalist. His book "Ukraine: the Scale 1:1" won the first prize in the Competition of Artistic Reportage named after Mike Johansen in 2013. He was working on it for five years. According to him, it was an attempt to "explore some archetypes, to understand the elusive but constantly referred to idiom of "Ukrainian mentality" [6, p. 377]. At the base of the book there are real facts from the life of O. Khryshtopa-journalist, which he had been recording for eight years, traveling around Ukraine. The cartography of his travels and assignments to different corners of the country covers a number of small and large cities: Dnipropetrovsk, Zaporizhzhia, Ivano-Frankivsk, Kyiv, Kirovohrad, Kosiv, Makiivka, Odessa, Pyriatyn, Poltava, Uzhorod, Chyhyryn and others.

O. Kryshtopa wrote a collection about Ukraine with the dedication: "To my grandfather Slavik and Tolik Kuzmenko" [6, p. 3]. The artist showed his own imaginative and emotional world in his artistic reportages. The starting point in the stories is always Kiev, where the journalist has been living since 2004 .

The author reproduced urgent topics: unemployment, employment abroad, language, politics, ecology, coal fever, Chornobyl. His reportage "Chornobyl Safari" reproduces the forgotten reality, shows pictures of historical and ecological disasters: looting, returning of former inhabitants to the area, excursions with stalkers, transformation of catfish into "Chornobyl crocodiles" and more. O. Khryshtopa has chosen the darkest colors for the image of Chornobyl, rightly calling it a "dead city" [6, p. 136], devolving the state of the settlement. The society has long associated Chornobyl with a dead zone. The author tried to show that despite the environmental and social difficulties, life in the exclusion zone continues.

The images of the nature introduced into the text reproduce the author's frustration from contemplation of the gloomy landscapes: "And here, on the mountain, a tree sprouted from the floor. It is young, frail, but it lives..." [6, p. 141], "For the last few days, death is chasing me" [6, p. 261], "There was not a single living soul for a few kilometers" [6, p. 56], "Shakhtarsk, Torez and Snizhne died, when the mines were closed" [6, c. 30], "Red cones lined up in a row. The first, the second, the third. The slagheaps look somewhat like giant anthills" [6, p. 30]. He calls Donetsk a city that "... readily admits but is very reluctant to let go" [6, p. 23]. The metaphor summarizes the journalist's sensation from each trip: "... my body remembers these always terrible roads, so that sometimes it jumps by itself even where a pit was patched" [6, p. 12]. Landscapes near the station are metaphorically embodied. The author represents very emotionally how, next to the unfinished sixth and seventh units of the NPP, “... tower cranes powerlessly lowered their arrows, holes are gaping in the pipes, voids are visible through them, there are pieces of tin and concrete around" [6, p. 133]. The metaphor in the author's artistic reportage is the most widespread means of putting into words associative impressions of the usual processes: "Barely noticeable, faded white arrows against a blue background drive your car into impassable 
jungle" [6, p. 23]. Landscapes perform the following functions: they reproduce the longestablished pantheistic worldviews: "When the sun begins to go slowly down, the color changes ..." [6, p. 51]; the scenes of nature inspire: "Any landscape is hidden behind the thick greenery at the side of the road" [6, p. 47]; visualize the places, where he happened to visit: "The sloping hillsides covered with vineyards" [6, p. 48], "The narrow green streets were stretching up. Buildings merged into one ..." [6, p. 49], "The Bogdan's mountain was looming over Chyhyryn" [6, p. 162].

The artist reinforces the imagery by correlating it with processes that are not characteristic to them: "The sun warms the land and it begins to smell spring" [6, p. 14], "I almost do not remember that trip - it was all sunk (that was the key word) in the holidays, the Carpathian vertep" [6, p. 164] and clearly demonstrates his presence in the text: "Ivan Dmytrovych approaches us, he in the first days after the flood, together with rescuers, scoured the field in search of drowners" [6, p. 188]. He deliberately creates emotional tension: "And all their pain, all sadness, all regret to themselves suddenly boil in the clouded mind with malice just to another world unfair to them" [6, p. 35], to show the mechanism of understanding people's problems. In the reportage of "The Hero of Not Our Time" the author explains the essence of the story in which the former prisoner tried to "... turn the train of history" $[6$, p. 211] of 90s of the XXth century. Metonymic transfers are expressions of reduced speech and doubling of information. To denote the generalized opinion of the inhabitants the name of the settlement was transferred: "People of Chornobyl say that when the church was rebuilt, five priests arrived at a time, all by jeeps" [6, p. 155]. We learn the fact that looting does not disappear as a phenomenon, from the lines: "The forest is cut down. Even in this desolation, even after many years after the accident, people demonstrate their worst features..." [6, p. 141-142]. The metonymic expression of "logging" emphasizes the fact of cutting down every tree. The author uses his own names in the sense of the common ones ("Europe and America understood this in the second half of the twentieth century ..." [6, p. 26] or: "Neither Lenin nor Stalin will do anything about it" [6, p. 228]), to create a double sense of the phrase, decoding images of the most influential parts of the planet and previous political leaders. O. Kryshtopa uses the name of a song or an interactive form of the story instead of the residents who lead them ("Carols and loud drunken conversations got silent" [6, p. 193]) to demonstrate the absolute silence that can occur when important news is reported.

In reportage "Traumatism" the author, describing the type of active recreation, emphasizes that "on wheels" means "to skate": "We have spent the last few weeks on wheels" [6, p. 216]. The author transfers the meaning of the name of the performers to the proper name: "The large tent with the inscription POLTAVA took care of cleanliness and order" [6, p. 217] in order to clarify the actions of the cleaning participants. In the same report, the author depicts the leisure of the guests of the capital, who "... in their spare time from work at the Maidan chased a ball ..." [6, p. 217], that is, they played football. In the text "Suitcase , Station ... Ukraine", he refers to the image of a "person" who feels no boundaries between the states: "One leg is here, the other is there" [6, p. 11].

Actually the author's aesthetic meanings are represented by A. Khryshtopa's using simple comparisons: "The whole economy of this country only sticks to the fact that it is in the "shadow" - everyone, like a hamster, hides from the state, and stuffs the food behind his cheeks "for a rainy day" [6, p. 379] or: "Seeing strangers, they, like cockroaches, instantly burrow and lock their iron doors" [6, p. 34]. The instant process of people escaping from strangers the author likens to the actions of cockroaches. Significant shortcomings of Ukrainian roads are outlined in the lines: "The car is swinging, as if on waves and many feel seasick on land " [6, p. 47]. The artist conveys the usual feelings: "Natalka seemed to feel like a fish in Kalmius in Donetsk" [6, p. 21]. In the reportage "Atlantis" during the flood, the houses are identified with playing cards: "They cracked as if they were made of cards" [6, p. 166]. The military unmistakably identify the danger by hearing, as the smallest members of society do: "... that with this monotonous chattering quietly leave school" [6, p. 14]. O. Kryshtopa describes the impression of the new town: 
"Vynohradiv. The city is surrounded by a moat, as if in the Middle Ages. There is a road between two ramparts" [6, p. 173]. The author resorts to the means of comic relief, irony in particular, calling the convict M. "a romantic being a highway robber" [6, p. 209].

The sound images give the reportages truthfulness and confirms that the author was indeed at the place depicted with the smallest detail: "From afar the explosions of change are heard. Gup-gup-gup..." [6, p. 44]; "The sea is around and everything comes and comes, and sounds: only crack, crack, crack, boom" [6, p. 166]. The author emphasizes the feeling of sadness in the reportage "Atlantis", which describes the post-flood landscapes of Transcarpathia: "But it was near. And those... and that road there is long, and we sail there, but as the water rushed into the boat, so that was it. It went...” [6, p. 187]. In order to increase the feeling of insecurity of people, the narrator repeats: "Fear, fear, when all the houses were moving ..." [6, p. 166], and people remained powerless against the cataclysm of nature; "And they dig, they dig, they dig in search of the black gold" [6, p. 32].

The author places emphasis on poetic microimages in the texts of his artistic reportages with stylistic figures. O. Khryshtopa resorts to amplification in order to capture events in a frame-by-frame manner: "In the frame, lights come on, the film cracks. The dosimeter howls like a fire siren. Some screams are heard, the race starts again" [6, p. 135], "This place outside reminds of Eden. Water, lots of water, a sea of water, the sun, warmth and mountains "[6, p. 48]. With the accusatory purpose the author uses dysphysisms: "... it was necessary to go on a tree, not everyone agreed respectfully, some pooed into their pants ..." [6, p. 43], or: "We stopped and went out to piss" [6, p. 162], people "climb in the mines on their hands and knees" [6, p. 32].

Parceling is a frequent stylistic technique for artistic reportages. The author divides the sentence into syntagms: "Power lines. Concrete floors. Hills behind which the first, the second, and the third reactors are recognised. Finally the sarcophagus with the tube" $[6$, p. 134], reproducing a picture after picture. Parceling the story helps to reveal the mood of the society: "- I can't stay here anymore. Cramped. Cramped! I'll leave. With you, or myself, but I will leave" [6, p. 19], to focus at the background of the image and on visual images themselves: "I have not seen so many cats in any other place. On trees, on roofs, windowsills, streets, fences, underfoot. Everywhere. Red, black, yellow, even green, Siamese, fluffy, stagy, on four, three, two paws or even legless" [6, p. 49]. The author creates an editing effect, combining different time intervals, for example, his own summer holidays, which were monotonous: "The beach, the stadium, the mulberry tree, the veranda, where my great-grandmother was doing household chores near the cooker with a gas cylinder. Zucchini and eggplants, apricots and strawberries. Fishing and chess" [6, p. 160], situations, locations on the map and etc. O. Kryshtopa is parceling the story, describing the "dead" mining towns: "On one of the hills, from which the whole city and all its pipes are clearly visible, there is a cemetery. Pipes and crosses. Lots of fresh crosses. You walk in the rows and look at the years of birth and death, calculating the average life expectancy. 45 , $39,55,59,25,28,33,34$. Few lived till 60" [6, p. 28].

Asyndeton is one of the ways of rethinking history: "German soldiers broke doors, searched homes, peeked into cellars. They caught all men of conscription age and drag them to the local school" [6, p. 269].

For the most part literary allusions appear in reportages. For example, the sound engineer, who has not drunk vodka for four years quotes the famous phrase from the comedy W. Shakespeare: “- To drink or not to drink, that's the question" - he replies in a Shakespearean way, only addressing not the skull, but the glass". [6, p. 174]. O. Khryshtopa uses allusion as an extra-textual phenomenon, pointing to the authority of the artist and his work of art: "Then everything was like Hemingway. The old man and the sea ...” [6, p. 234]. He compares K. Marks and G. Marquez, considering the paronymicity of their surnames. In the title of the artistic reportage "One Hundred Years of Karl Marquez's Solitude", O. Khryshtopa recounted a story about the billboard that featured K. Marks. Each time passing the billboard, the narrator metaphorizes that K. Marks will never lose his place, because he returns: "To his eternal loneliness" [6, p. 292]. The title is 
an allusion to Yu. Lermontov's novel "The Hero of Our Time", because the fatalist in O. Khryshtopa's story died too.

The author interprets "alien" images in his artistic reportages. The sources of intertext in O. Khryshtopa's plots were images of national and foreign literature, cultural and historical figures, phenomena, etc.

O. Kryshtopa uses proverbs from people's life in his texts: "In ancient times, rushing was considered to be worth of condemnation: do not go before your father into hell, if you hurry you'll make people laugh, etc. Proverbs remained, the pace of life has changed, and now vice versa someone's slowness and equability of mind make other people laugh and even disrespect" [6, p. 287].

In the text "The Horison of the World" to decipher the end of the world as a projection to a real event, the artist emphasizes that this is not a place like that of T. Shevchenko, where "according to the legend small Shevchenko went to search for - to the neighboring village" $[6$, p. 96]. The basis is the real story of a 19 years old son of well-to-do parents, who became the culprit of the crashes that happened simultaniously. The edge of the world begins where the road and arbitrariness of drivers start: "I found this part of the world. By accident, but found ... We were making a documentary for 1+1 Channel entitled "Careful, a silver-spooner is driving" [6, p. 96].

The title of the reportage "The Idiot's Dream" is a reminiscence of a phrase from I. Ilf and V. Petrov's novel "The Golden Calf". It is treated as a strange, the most desirable dream. O. Khryshtopa depicts the dream of a local alcoholic to buy the most expensive wine in the distillery. In the end, the narrator sums up: "But while she asks him to show it, not everything is lost" [6, p. 215].

In the reportage "The Lighthouse" the narrators are Yurii Ivanovych and Captain Pechkin (a name possibly borrowed from the Soviet cartoon featuring Mailman Pechkin, who embodied the flaws of the Soviet society). Yurii Ivanovych performs the duties of Ukrainian caretaker "... of the Russian lighthouse at the Ukrainian territory. At home among strangers, a stranger among his own people" [6, p. 62]. The author calls him "Don Quixote struggling with windmills, a Russian-speaking Ukrainian, who declared a war to the Russian Black Sea Fleet" [6, p. 62].

The reportage "The Great Ukrainian Depression" is equated with the environmental depression: "Yellow Pazzas with black stripes on their sides roam the city buried alive in search of young dead..." [6, p. 29-30]. American Great Depression is nothing, unlike the most dramatic environmental situation in the "impassable jungle of industrialization" [6, p. 23], which exists in the mining settlements and small towns of Donetsk region.

The intertextual means stylize contemporary situations by referring to different plots. A dialogue is created between the texts of O. Khryshtopa and other writers, which confirms the relevance of the topic or the problem in the content of the text. Thus, the artistic reportage has particular poetic-style dominants that allow us to trace the linguistic and stylistic organization of the text.

Conclusions. Therefore, taking into account the current transformational processes that take place in the genre system of the Ukrainian literature, the appearance of the artistic reportage is a logical phenomenon. We are sure that it is a meta-genre in documentary and artistic discourse. As a meta-genre, the artistic reportage is only beginning its appearance in the contemporary Ukrainian literature.

Modern non-fiction literature is developing dynamically and requires literary analysis. The rapid development of the artistic reportage texts is caused by the influence of the information boom we see today, the expansion of the thematic range of topics and the desire of young authors to join the global literary context. Undoubtedly, the artistic reportage is a new genre of non-fiction literature, and therefore fully meets the requirements of the modern literary world.

In his book "Ukraine: 1:1 the Scale" O. Khryshtopa skillfully uses linguistic and imaginative means to create visual and audio images. Artistic reportages have a dual nature 
because they synthesize genre features of literature and journalism. We consider that the study of the artistic reportage genre specificity will be the subject of the further research.

\section{СПИСОК ВИКОРИСТАНИХ ДЖЕРЕЛ}

1. Бовсунівська Т. Теорія літературних жанрів: Жанрова парадигма сучасного зарубіжного роману : підруч. Київ : Видавничо-поліграфічний центр «Київський університет», 2009. 519 с.

2. Галич О. Література non fiction: теоретичний вимір: монографія / упоряд. Т. Ю. Черкашина; наук. ред. О. А. Галич. Київ : Видавничий дім Дмитра Бураго, 2018. $272 \mathrm{c}$.

3. Дончик В. Український радянський роман : рух ідей і форм. Київ : Дніпро, 1987. $429 \mathrm{c}$.

4. Ільницький О. Український футуризм (1914-1930) / пер. $з$ англ. Р. Тхорук. Львів : Літопис, 2003. 456 с.

5. Копистянська Н. Жанр, жанрова система у просторі літературознавства. Львів : ПАIC, 2005. $368 \mathrm{c}$.

6. Криштопа О. Україна : масштаб 1:1. Київ : Темпора, 2017. 392 с

7. Літературознавча енциклопедія : у 2-х т. / авт.-укл. Ю. І. Ковалів. Т. 2. : М - Я. Київ : ВЦ «Академія», 2007. 624 с.

8. Рарицький О. Художньо-документальна проза як метажанр : проблема рецепції та інтерпретації, особливості вияву й функціонування. Слово $i$ час. 2014. № 11. C. $37-48$.

9. Титаренко М. Ключі до нон-фікшну: правдивіше за саму реальність. URL : http://litakcent.com/2017/01/13/kljuchi-do-non-fikshnu-pravdyvishe-za-realnist/ (дата звернення : 03.01.2020).

10. Тодоров Ц. Походження жанрів / пер. з франц. Є. Марічева. Поняття літератури ma інші есе. Київ : ВЦ «Києво-Могилянська академія», 2006. С. 22-39.

11. Цимбал Я. Флірт із нарисом і фактова література. Шляхи під сонцем. Репортаж 20-х років. Київ : Темпора, 2016. С. 5-18.

12. Цимбал Я. Як створювався український репортаж? URL : https://day.kyiv. ua/uk/article/media/yak-stvoryuvavsya-ukrayinskyyreportazh (дата звернення : 20.12.2019).

13. Шкловский В. Литература факта. Гамбургский счет : Статьи - воспоминания эссе (1914-1933). Москва : Советский писатель, 1990. С. 393-425.

14. Шутяк Л. Американський та український «новий журналізм»: компаративний аспект. Теле-та радіожурналістика: зб. наук. пр. Львів: Вид-во ЛНУ ім. І. Франка, 2013. Вип. 12. С. 410-414.

15. Яремчук О. Факт проти вигадки у літературному репортажі. Вісник Львівського університету. Серія Журналістика. Львів: Вид-во ЛНУ ім. І. Франка, 2018. Вип. 44. С. 95-100.

16. A Historical Anthology of Literary Journalism : The Art of Fact / by K. Kerrane and B. Yagoda. Touchstone, 1998. 558 p.

\section{REFERENCES}

1. Bovsunivska T. Literary Genres Theory. Genre paradigm of contemporary foreign novel : textbook. Kyiv : Publishing and printing centre "Kyiv University". 2009. 519 p.

2. Halych O. The non fictional literary: Theoretical dimension/monograph/authorcompiler T. Y. Cherkashyna; scientific-editor O. A. Halych. Kyiv : Publishing house by Dmytro Buragho's, 2018. 272 p.

3. Donchyk V. Ukrainian Soviet novel : the motion of ideas and forms. Kyiv : Dnipro, 1987. 429 p.

4. Ilnytskyi O. Ukrainian Futurism (1914-1930) / trans. from English. R. Tkhoruk. Lviv : Litopys, 2003. 456 p. 
5. Kopystianska N. Genre, the genre system in the space of literary criticism. Lviv : PAIS, 2005. $368 \mathrm{p}$.

6. Khryshtopa O. "Ukraine : the Scale 1: 1". Kyiv : Tempora, 2017. 392 p.

7. Encyclopedia of Literary Studies : in 2 volumes/ author Kovaliv Yu. Kyiv : Publishing center "Akademia", 2007. V. 2. 624 p.

8. Rarytskyi O. Docufiction as a meta-genre : reception, interpretation, manifestations and functioning. Slovo i chas. 2014. № 11. P. 37-48.

9. Tytarenko M. Keys to non-fiction: more true than reality itself. URL : http://litakcent.com/2017/01/13/kljuchi-do-non-fikshnu-pravdyvishe-za-realnist/ (accessed : 03.01.2020).

10. Todorov Ts. Origin of genres / trans. with the French. E. Maricheva. Concepts of literature and other essays. Kyiv: Publishing center "Kyiv-Mohyla Academy", 2006. P. 22-39.

11. Tsymbal Ya. Flirting with essay and factual literature. Ways under the sun. Reportage of the 20's. Kyiv : Tempora, 2016. P. 5-18.

12. Tsymbal Ya. How was the Ukrainian reportage made? URL: https://day.kyiv ua/uk/article/media/yak-stvoryuvavsya-ukrayinskyyreportazh (accessed : 20.12.2019).

13. Shklovskyi V. The literature of fact. Hamburg Account : Articles-Memories-Essays (1914-1933). Moscow : Soviet writer, 1990. P. 393-425.

14. Shutiak L. American and Ukrainian "new journalism" : a comparative aspect. Television and radio journalism : coll. of sciences. Lviv: I. Franko Publishing House of LNU, 2013. Vol. 12. P. 410-414.

15. Yaremchuk O. Fact against fiction in literary reportages. Bulletin of Lviv University. Series : Journalism. Lviv : I. Franko Publishing House of LNU, 2018. Vol. 44. P. 95100.

16. A Historical Anthology of Literary Journalism : The Art of Fact / by K. Kerrane and B. Yagoda. Touchstone, 1998. 558 p.

Received: 27 March, 2020 